\title{
Pius Adesanmi: The Man Who Leaves and Lives
}

\author{
Toyin Falola \\ University Distinguished Teaching Professor \\ Jacob and Frances Sanger Mossiker Chair in the Humanities \\ The University of Texas at Austin \\ toyinfalola@austin.utexas.edu
}

\author{
Death, captured in a box \\ suspended in mid-air \\ Slowly ascending to land on a rock \\ too far to see. \\ The phantom is bold \\ Killing the scion of creativity and talent
}

\section{A Fallen Branch}

None of us can determine the frequency of death and predict the timing of its occurrence. You and I are slaves to the monster. Almighty death snatched away our precious jewel. Ikú d'óró, iku' șèà. The death that cut Pius in his prime stings with sorrow. An irreplaceable man has gone. A silence descended upon me, a pregnant silence. I could not even recover to write this tribute, doing so only after request by friends and his family members. The sorrow is difficult to bear. The pain refuses to leave.

A branch has fallen

Stricken down by Șàngo

The god of thunder

Stolen by death

To appease O'gún, the god of iron

Do you demand a sacrifice?

Why not collect a chicken?

Yes, death has violently collected an offering by violence 
A hawk sweeping the chicken off the ground

Mother hen is powerless

A sting of death that refused appeasement

Orunmila, why do you look away?

No emissary to the forest

To prevent the Irok ko from falling

Killing the tallest tree in the jungle

Șokotí, Alágbẹ dẹ Ộrun

Sokotí

Șokoti forged and pounded metal, to create and destroy

\section{Orphanage}

It is my joy in life to find

At every turning of the road

The strong arm of a comrade kind

To help me onward with my load.

And since I have no gold to give,

And love alone must make amends,

My only prayer is, while I live-

God make me worthy of my friends.

\section{Frank Dempster Sherman}

We all are the bereaved. We are worthy of Adesanmi's friendship but he has turned us into orphans. Pius did not see himself as a spiritual father to any. In collecting a large number of followers, he did so to transform Africa. His name will always be associated with change. He became an influential scholar shaping the minds of thousands of people, creating models for others to follow. Very rapidly, his influence spread across the continent, as he spoke about the power of knowledge, spreading words of comfort, addressing the relevance of resistance to power. He opened the way to a larger discourse on the limits of superstructure, while also creating a path to extensive reflections on the social and cultural formations of contemporary Africa. Focusing on quotidian lived experiences, he connected thousands of people with the bigger ambition of the application of modernity. Pius's energy and enthusiasm for everything that life had to offer was infectious and inspiring. Those who knew him would admire his strength, his passion, his resilience, his exuberance, and his adorably audacious character. I happen to be one of those. I always knew him as someone that could do anything-positive, creative, beautiful. He was fiercely proud of his heritage, and he would tell vivid stories of his childhood days in colorful, folkloric detail. I salute his immortal 
spirit and know that though he is with God now, his life force will be here on Earth with us forever.

Pius stood for something that is in short supply: He was a mentor to many people. He gave to others without asking for anything in return, thus generating a kind of moral authority. He had the power of conviction, the aura of incorruptibility. He spoke truth to power, unafraid of intimidation by those in power. He did not seek power, and was never beholden to it. He was a genuine human being. He believed in his words, and he did not utter them out of personal aggrandizement. He stood for what he knew to be true and just, and always. Like Amilcar Cabral, he saw the people as the core of nationalism, and he challenged them to stand up for their rights, to see themselves as having agency.

His death has thrown many into an orphanage. One orphan, Dr. Samuel Oloruntoba, based in South Africa, wrote to me with tears in his eyes:

I don't have a strong emotion to withstand this type of shock. At a point yesterday, I just lied down flat on the bare floor of my office to ask God how to cope with this. This has nothing to do with the plans that we had together but the void that has been left-on the ideals that he stood for, his mother, who served us pounded yam in their Ilorin home in July last year, his wife and daughter and the manner of the tragic death. I hit myself intermittently. Could I have seen a revelation and warned him not to go on this journey? I can't look at his pictures going around without feeling that a part of me is gone.

Ibrahim Odugbemi, one of his admirers, went into an agonizing reflection:

The death of Oga Adesanmi makes me empathize with myself and all others of my species. We, these near-God beings created in God's image (Bible), sent to Earth as God's representatives (Quran), more than all other creatures, we have so many features of God -- knowledge (of art, science, technology etc.), spirituality/faith (which is all that Angels have, and where they compete fiercely with us), free will (isn't God Aseyowun?). But we don't have the capacity to live forever in this world.

Dr. Bode Ibironke of Rutgers University, an interlocutor, was seized with fear:

The last time I saw Pius was in Michigan, at a conference organized by Ken Harrow. We were on the same panel. He made everyone laugh as he threaded together satirical narrative and theoretical arguments. His charm, 
his brilliance, his confidence, and his special skill in human connection made him so attractive. It was unthinkable to contemplate his disappearance. How could one not tremble? What sort of gift is life when it's never really our own?

As I reflect on the words of the orphans, I am reminded once again of the danger that death brings to the world:

Ikú bọlá jẹ!!

Ikú bará jẹ!!

Ikú gé wa l'ódòdó èyẹ!

Kin ni ká ti wí?

Kin ni ká ti sọ?

Igi táa ní ká fi rólé,

Igí dá porogodo!

Kín ni ká ti wí?

Kín ni ká ti sọ?

Igi tó ń rúwé lọwọ!!

Igi tí ń gbọrợjigọ l'ójúu tẹbí, tará, tọrẹe!

Kin ni ká ti wí?

Kín ni ká ti sọ?

Àfi gbì láìòti?

Ȧfi bí àlá!

Àfi bí oorun l'ójúu gbogbo wa!

Mo sunkúnsunkún;

Ojú mi ò dá mọ́.

Olóríburúkú ń bẹ nílẹ;

Ikú sòjóró; kò rí i.

Kin ni ká ti wí?

Kin ni ká ti sọ?

Ơfọ ńlá lèyí!

E ba mi ké gbàjarè!

Ká șijú ká ríran rere wò;

Ebora dá hiọhioo sílẹ!

\section{A Committed Thought}

Death, I won't appeal to you to kill no more

As you cannot be appeased

Shameless death

A thunder clap in a wild world 
I called him Àbúrò Nàijá, the generic name that I give to everyone born after the country's independence in 1960. They are different from those of us, Ègbọ́n Nàijá (those born before 1960) with another kind of cultural nationalism. If I grew up in the age of blackboard and chalk, Àbúrò Nìija grew up in the age of Facebook and Twitter, the age of rapid knowledge production, the age of CODESRIA and the African Union. If Ẹgbọn Nàijá is about face-toface conversation, the ojú lọrọ wa in which you must see the person you are communicating with on a one-on-one basis, Àbúrò Nàijá is about participation in meetings and conferences where new theories emerge on a daily basis, and the world is connected by air travels.

What characterizes Àbúrò Nàijá's way is the rapidity and dynamism of his movement back and forth between academic and public engagements. Those in the literary world are usually not found in the policy world, but Pius was adept in literature and politics, art and economics. His methodology does not see society as consisting of silos, understandable as autonomous parts and without context. Domination, he argued over and over again, resides in the kitchen as well as in the palace. His spirit of vigilance warns us about decadence, death, and risky exchanges in African societies. He alerted us, as well as keeping us alert, to the preservation of what is good in us as a people.

Pius understood the core of the capitalist system, set against the context of the rural background of his parentage. He became audacious, seeking the ways to transform the rural into the modern, and means to tame capitalism into one with a soul. He resided in the heart of the capitalist system but his mind and spirit are in the rural. He successfully created a community of language to capture the minds of his commune. His Umma became eager listeners, and they began to share a common understanding about the future of Africa. As his reputation became established, he also became a catalyst and innovator, driving ideas around the empowerment of youth to create emancipatory movements, resistance tools, and national liberation. He mastered the art of combining praxis with logos, the ell of political criticism with theoretical debate, militant passion with sound intellectual substance.

Pius was a conscientious, meticulous scholar who graced his craft with wit, integrity, dedication, and enthusiasm. He sought coherence and wholeness in both theory and empiricism. The world is greedy, Pius warned us too many times-politicians exploit the citizens; rich countries exploit the poor ones. Merging creative writings with creative politics, Pius operated at the margins of disciplines, demanding that scholars have a responsibility to the poor, and must confront the transformations of the peasants and their rural societies.

I feel a sense of awe and gratitude for his solicitude and decency, for his opposition to injustice, his critical condemnation of politicians and their corruption and indiscretions. He had both human and intellectual qualities 
in abundance: when he wanted to, he could listen, obsessed with cordial fraternity.

\section{Good morning, Mrs. Muyiwa Adesanmi, lya Tise}

"The thief comes only to steal and kill and destroy; I came that they may have life, and have it more abundantly." John 10.10 .

Pius was already writing as if in retirement. God does not recall those who still have tasks to perform. God worked his prothesis in Pius. After all, people congratulate the potter and not the pot. Our people have the saying about the people ignoring the brave hunter who killed a leopard to admire the leopard. Pious Pius is the potter and the brave hunter.

I don't want to join others in the despondent song of Adieu. This is too depressing, too grave, rather cold. Instead, I want to bring his energy back to life, the very energy that he committed to you and me, the feat of bringing literature to serve and to shape policies and politics. Rise up, great one. Reincarnate in Kenya, as the Mwalimu. Let your spirit be reborn in others as great scholars. Rise up in references in books and as a reference point.

But is Pius dead? I know him to be alive. Ewo! I won't mourn without mitigation. I won't be sad as I live with the memory of his goodness, his art of living. Ó tì o (No way)! I won't be terrified by his permanent absence as I am grateful for his achievements. My spirit will not be desolated. Mi ò gbà (I refuse to accept the loss)! Africa's renewal is the marker of the presence of Pius-his death is an assurance of our self-renewal-renewal of devastated souls, the marker of peace, the deepest source of our hope. The nostalgia will not be about calamity, but about joy and happiness. Ayọ ni tiwa (Ours is joy inexhaustible)!

I will always see him as alive, as I require no imagination to see his warmth and laughter, his embrace of me and others, his ever-positive words of encouragement. His history will always be with me, a history of a home that was defined to include me, you, and humanity.

Muyiwa, iyawo Pius, I have no words to console you and your child for the loss of your loved one. I can only say and assure you that the whole world shares your pain. Indeed, you are not only in my heart but in the hearts of the whole world at this moment and I pray God to give you the courage and fortitude to bear the loss. I would like you to accept the comforting wisdom of the Yorùbá saying: Ká kú l'ọmódé kó yẹni sàn ju ká dàgbà ká má ládie irànà-It's more honorable to die young than to live to old age without being accorded a dignifying memorial service. As a I write, a great crowd of Nigerians are 
gathered at Abuja to keep vigil to honor your husband. And all over the world, your husband is being mourned. Therefore, it is too late for you to create a home of sorrow, as this would not be the true spirit of my brother. You cannot create a body of pain, as he gave you everlasting love. Your heart cannot keep anguish as my brother taught all of us joy. The exit of Pius should be replaced by the entry of Pious.

He is with us: in his ideas, his contempt for hierarchy, his radical thoughts on the rejection of accepted ideas and poor reasoning. We will always remember him as an organizer. His foot soldiers on Facebook recognize, respect, and love him. Those in power will, of course, not miss him because of his criticisms of their incompetence and mismanagement.

Our brother has left his heart behind, to go to a home. Where-ever he may be now, I know that the doors and windows to his home are open, to you and me, they and us, we and they, the colors of the world. He looks, he gazes, he talks, he laughs, he reads, he listens, and all what our brother can see is hope in you, hope in us, hope in we, hope in them.

He is not dead. He cannot die. The tumult of life is different from the history of life. For a heart so large, in clouds and sun, rain and hurricane, our brother will always be here. His heart, large and compassionate, will continue to beat in your presence, in my presence, in our presence, in their presence. Pius lived a fulfilled life full of legacies that few can equal.

Pius, dream in peace with the ancients. Good night. 